\title{
EDUKASI "SADARI” (PERIKSA PAYUDARA SENDIRI) UNTUK DETEKSI DINI KANKER PAYUDARA DI KELURAHAN CIPAYUNG KOTA DEPOK
}

\author{
Rafiah Maharani PULUNGAN1, Fathinah Ranggauni HARDY2 \\ Prodi Kesehatan Masyarakat, Fakultas IImu Kesehatan \\ Universitas Pembangunan Nasional Veteran Jakarta \\ Email: rafiah.maharani@upnvi.ac.id
}

\begin{abstract}
The problem of breast cancer and the impact it has created will require public health interventions in the form of a national countermeasure program regulated in Permenkes No. 34 of 2015 concerning Management of Breast Cancer and Cervical Cancer. One of the prevention of breast cancer is case finding with early detection which is done through Breast Self-Examination (BSE) which can be done easily which aims to determine the presence or absence of a lump that can develop into breast cancer. One of the prevention of breast cancer is case finding with early detection which is done through Breast Self-Examination (BSE) which can be done easily which aims to determine the presence or absence of a lump that can develop into breast cancer. The purpose of this activity is to increase knowledge, and change behavior about early detection of breast cancer through Breast Self-Examination (BSE) in Cipayung Village, Depok City. The target audience for this service is the Health Officers and Cadres in the Puskesmas, and especially the mothers in Cipayung Village. The method of implementation of this community service includes the preparation, implementation and evaluation stages. In the preparation stage it was shown that all participants had never received education about BSE before, even $95 \%$ of the 32 participants had just heard about BSE. Low initial knowledge can be seen from the results of pretests conducted in which the majority of mothers' level of knowledge is still low about breast selfexamination and breast cancer after education and training there is an increase in maternal knowledge about breast self-examination. It is recommended that health workers regularly provide education about breast self-awareness to women, especially mothers.
\end{abstract}

Keywords: Education, BSE, Breast Cancer

\section{ABSTRAK}

Besarnya masalah kanker payudara dan dampak yang ditimbukan maka perlu tindakan/intervensi kesehatan masyarakat dalam bentuk program penanggulangan nasional yang diatur dalam Permenkes No. 34 Tahun 2015 tentang Penanggulangan Kanker Payudara Dan Kanker Leher Rahim. Salah satu penanggulangan kanker payudara yaitu penemuan kasus dengan deteksi dini yang dilakukan melalui Pemeriksaan Payudara Sendiri (SADARI) yang bisa dilakukan secara mudah yang bertujuan untuk mengetahui ada tidaknya benjolan yang dapat berkembang menjadi kanker payudara.

Tujuan dari Pengabdian ini adalah untuk meningkatkan pengetahuan, dan perubahan perilaku tentang deteksi dini kanker payudara melalui Pemeriksaan Payudara Sendiri (SADARI) di Kelurahan Cipayung Kota Depok. Sasaran khalayak dari pengabdian ini adalah Petugas Kesehatan dan Kader di 
Puskesmas, serta terutama Ibu-ibu di Kelurahan Cipayung. Metode pelaksanaan dari kegaitan pengabdian ini meliputi tahap persiapan, pelaksanaan dan evaluasi.

Pada tahap persiapan menunjukkan bahwa semua peserta tidak pernah mendapat edukasi tentang SADARI sebelumnya bahkan $95 \%$ dari 32 peserta baru pertama kali mendengar tentang SADARI. Pengetahuan awal yang rendah terlihat dari hasil pre-test yang dilakukan dimana mayoritas tingkat pengetahuan ibu masih rendah tentang SADARI dan kanker payudara setelah dilakukan edukasi dan pelatihan terjadi peningkatan pengetahuan ibu tentang SADARI. Disarankan kepada petugas kesehatan secara berkala memberikan edukasi tentang SADARI kepada wanita khususnya ibu.

Kata Kunci: Edukasi, SADARI, Kanker Payudara

\section{PENDAHULUAN}

Penyakit kanker saat ini adalah satu dari penyebab utama kematian di seluruh dunia. Tahun 2030 diperkirakan akan meningkat menjadi 26 juta penderita dan 17 juta di antaranya meninggal dunia akibat kanker (WHO, 2015). Kanker menjadi masalah kesehatan masyarakat di Indonesia dengan prevalensi 136.2/100.000 penduduk. (kemenkes, 2019). Salah satu kanker yang paling banyak diderita terutama pada wanita yaitu kanker payudara. Tahun 2012 kanker payudara adalah penyakit kanker dengan proporsi tertinggi sebesar $43,3 \%$, dengan insidensi 40 per 100.000 perempuan dan persentase kematian akibat kanker payudara sebesar 12,9\%. (Globocan, IARC 2012). Angka kejadian kanker payudara tertinggi pada perempuan yaitu sebesar 42,1 per 100.000 penduduk dengan rata-rata kematian 17 per 100.000 penduduk yang diikuti kanker leher Rahim. (Kemenkes,2015)

Kanker payudara mayoritas berusia muda, bahkan tidak sedikit yang baru berusia 14 tahun dan jika tidak terdeteksi lebih awal akan berkembah menjadi sel ganas. Saat ini menunjukkan bahwa tren gejala kanker payudara yang semakin tinggi di usia remaja. Di Indonesia, lebih dari $80 \%$ kasus ditemukan berada pada stadium yang lanjut, dimana upaya pengobatan sulit dilakukan. Oleh karena itu perlu pemahaman tentang upaya pencegahan, diagnosis dini, pengobatan kuratif maupun paliatif serta upaya rehabilitasi yang baik, agar pelayanan pada penderita dapat dilakukan secara optimal.

Besarnya masalah kanker payudara dan dampak yang ditimbukan maka perlu tindakan/intervensi kesehatan masyarakat dalam bentuk program penanggulangan nasional yang diatur dalam Permenkes No. 34 Tahun 2015 tentang Penanggulangan Kanker Payudara Dan Kanker Leher Rahim. (Kemenkes 2015) Salah satu penanggulangan kanker payudara yaitu penemuan kasus dengan deteksi dini yang dilakukan melalui pemerikasaan payudara klinis atau Clinical Breast Examination (CBE) serta Pemeriksaan Payudara Sendiri (SADARI) yang bisa dilakukan secara mudah oleh wanita. SADARI merupakan teknik pemeriksaan payudara sendiri yang bertujuan untuk mengetahui ada tidaknya benjolan yang dapat berkembang kanker dalam payudara wanita (Ayu, 2016)

Teknik SADARI sangat mudah dilakukan namun banyak perempuan khususnya remaja yang tidak mengetahui cara ini serta masih banyak remaja masih tidak peduli dan peka terhadap gejala-gejala abnormal pada payudara mereka. Hal tersebut juga disebabkan oleh kurang informasi dan motivasi untuk mendapat informasi mengenai pencegahan dan deteksi dini kanker payudara. SADARI juga terasa masih awam dan remaja risih untuk melakukannya, menyebabkan masih sedikitnya jumlah wanita yang rutin melakukan SADARI sesuai waktu yang ditentukan (Anggrayni, 2017)

Kanker payudara mayoritas di derita oleh perempuan, sering penderita datang ke pelayanan kesehatan ketika sudah memasuki stadium akhir dimana sudah sulit dilakukan pengobatan. Penanganan yang penting yaitu melalui SADARI dimana setiap perempuan dapat melakukan pemeriksaan payudara sendiri. SADARI adalah pengembangan kepedulian seorang perempuan terhadap kondisi payudaranya sendiri. Tindakan ini dilengkapi dengan langkah-langkah khusus untuk mendeteksi secara awal penyakit kanker payudara untuk mengetahui perubahan-perubahan yang terjadi pada payudara. SADARI bertujuan untuk mengetahui ada tidaknya kanker payudara pada wanita. 
Kelurahan Cipayung Kota Depok memiliki total Kepala Keluarga sebanyak 2.326 KK dengan jumlah penduduk sebanyak 29.872 jiwa dengan distribusi dan proporsi menurut jenis kelamin sebagian besar ialah perempuan dengan proporsi sebesar (53\%) sedangkan laki-laki sebesar (47\%). Proporsi penduduk berdasarkan tertinggi kedua ialah remaja akhir sebesar (17\%) dan Remaja Awal (12-16 tahun) sebesar $29 \%$.

Berdasarkan data dan wawancara dengan beberapa remaja di kelurahan cipayung kota depok bahwa mayoritas remaja tidak mengetahui tentang SADARI dan deteksi dini kanker payudara serta pencegahannya. Berdasarkan analisis situasi juga diketahui belum pernah mendapatkan edukasi tentang SADARI dan deteksi dini kanker payudara serta pencegahannya pada wanita usia subur terutama Ibu-ibu di Kelurahan Cipayung Kota Depok. Hal ini juga dikonfirmasi dengan petugas kesehatan dan kader di wilayah puskesmas bahwa belum pernah dilakukan edukasi ataupun promosi kesehatan mengenai SADARI pada remaja di wilayah ini. Tujuan dari Pengabdian ini adalah untuk meningkatkan pengetahuan, dan perubahan perilaku tentang deteksi dini kanker payudara melalui Pemeriksaan Payudara Sendiri (SADARI) di Kelurahan Cipayung Kota Depok

\section{METODE PELAKSANAAN}

Solusi yang ditawarkan adalah perlu dilakukan edukasi terhadap remaja putri di kelurahan Cipayung Kota Depok. Program SADARI sendiri dapat menekan angka kematian akibat kanker payudara hingga 20\%. Risiko perempuan yang tidak melakukan SADARI secara rutin akan lebih tinggi dari perempuan yang rutin melakukannya. Dimana 7 kali memiliki risiko untuk terkena kanker payudara dibandingkan dengan perempuan yang melakukan SADARI sebagai upaya deteksi dini. Kegiatan yang dilakukan untuk meningkatkan prilaku SADARI pada remaja di Kelurahan Cipayung meliputi:

1. Focus Group Discussion (FGD) dengan petugas kesehatan puskesmas Cipayung

2. Sosialisasi dengan Kader-kader kesehatan di wilayah kerja puskesmas Cipayung

3. Edukasi kepada Ibu-ibu mengenai Kanker payudara dan pencegahannya

4. Edukasi kepada lbu-ibu tentang teknik SADARI dan pentingnya melakukan SADARI

Secara teknis metode pelaksanaan adalah dibagi dalam beberapa tahap, yaitu

1. Tahap Persiapan

a. FGD dengan petugas kesehatan, kader puskemas

b. Mengurus surat ijin dari FIKES UPNVJ ke kelurahan dan puskesmas Cipayung

c. Menentukan jadwal pemberian edukasi tentang kanker payudara dan pelatihan SADARI

d. Menyusun materi / isi edukasi, yaitu :

1. Pengertian dan stadium pada kanker payudara

2. Gejala dan tanda kanker payudara

3. Faktor risiko kanker payudara

4. Pengertian dan cara melakukan SADARI

5. Manfaat SADARI

e. pembuatan media edukasi berupa leaflet, video SADARI, dan media patung tubuh

2. Tahap pelaksanaan:

a. Melakukan pre test untuk mengetahui tingkat pemahaman remaja tentang kanker payudara dan deteksi dini SADARI

b. Memberi Edukasi

c. Melakukan pelatihan dan praktek SADARI

d. Melakukan post test

3. Tahap evaluasi

a. Penilaian hasil edukasi SADARI

b. Memantau perilaku Ibu-ibu apakah sudah mempraktekan SADARI Sesuia yang di anjurkan 


\section{HASIL DAN PEMBAHASAN}

Tahap persiapan adalah Pengurusan surat Izin ke Mitra Pengabdian yaitu kelurahan dan puskesmas Cipayung Depok sudah dilakukan sebelum penyusunan usulan kegiatan. Sosialisasi kembali kegiatan secara menyeluruh kembali dilakukan pada bulan Agustus 2019. Tahap pertama adalah melakukan Focus Group Discussion (FGD) dengan staf Puskesmas penanggung jawab Program Promosi Kesehatan. Dari FGD yang dilakukan didapatkan bahwa belum pernah dilakukan promosi kesehatan tentang "Pemeriksaan Payudara Sendiri (SADARI) di Wilayah kerja Puskesmas Cipayung. Dan hasil dari FGD Tersebut dirasa penting untuk melakukan edukasi tentang SADARI kepada Ibu-ibu di Kelurahan dan Puskesmas Cipayung.

Persiapan selanjutnya adalah menentukan jadwal pemberian edukasi tentang kanker payudara dan pelatihan SADARI dengan ibu Kader di Kelurahan Cipayung. Setelah disepakati edukasi akan dilakukan di Majlis Taklim RW 1 Pondok Terong Kecamatan Cipayung dengan peserta adalah wanita Usia Subur khususnya adalah Ibu-lbu di wilayah kerja Puskesmas Cipayung pada tanggal 14 Agustus 2019.

Menyusun Satuan Acara Edukasi yang terdiri dari Pokok Bahasan, Sub Topik Bahasan, Sasaran, Tempat Penyuluhan, Waktu Pelaksanaan, Tujuan Umum, Khusus, Metode, Media Dan Alat Peraga, Pelaksana, Evaluasi, Sumber, Kegiatan Penyuluhan, Materi penyuluhan yang terdiri dari: Pengertian dan stadium pada kanker payudara, Gejala dan tanda kanker payudara, Faktor resiko kanker payudara, Pengertian dan cara melakukan SADARI, Manfaat SADARI

\section{Hasil pada Tahap pelaksanaan:}

a. Pada kegiatan edukasi dimulai dengan membuka kegiatan, lalu FGD dengan lbu-ibu peserta kegiatan, dilanjutkan dengan melakukan pre test untuk mengetahui tingkat pemahaman remaja tentang kanker payudara dan deteksi dini SADARI.

b. Memberi Edukasi dengan Menjelaskan tentang Pengertian dan stadium pada kanker payudara, gejala dan tanda kanker payudara, faktor resiko kanker payudara, pengertian dan cara melakukan SADARI, manfaat SADARI dan dilakukan diskusi

c. Melakukan pelatihan dan praktek SADARI

Pelatihan dan praktek SADARI dilakukan dengan media Manekin dan Video, setelah dijelaskan langkah-langkah sadari yang benar dilanjutkan dengan praktek ibu-ibu untuk mencoba melakukan SADARI. Lalu dilanjutkan dengan diskusi dan Tanya jawab

d. Setelah edukasi dan pelatihan selesai lalu dilakukan post test untuk mengevaluasi kegiatan

Dari tahap FGD yang dilakukan diketahui bahwa pengetahuan sasaran khalayah dal hal ini adalah lbuibu tentang SADARI dan kanker payudara masih rendah, mereka tidak tahu gelaja dan tanda awal kanker payudara. dari FGD ini juga diketahui beberapa Ibu memiliki faktor risiko seperti obesitas, pola makan, dan beberapa memiliki riwayat keluarga kanker payudara. beberapa ibu juga pernah merasakan keluhan sepert benjolan dipayudara namun tidak pernah memeriksakan diri ke pelayanan kesehatan. Hasil FGD juga menunjukkan bahwa semua peserta tidak pernah mendapat edukasi tentang SADARI sebelumnya bahkan 95\% dari 32 peserta baru pertama kali mendengar tentang SADARI. 5\% peserta sudah pernah mendengar tentang SADARI namun tidak tahu bagaimana mempraktekannya dan tidak mendapat informasi tentang manfaat dan langkah-langkah yang harus dilakukan. 5\% peserta tersebut mayoritas mendengar tentang SADARI dari media sosial namun tidak dipahami dengan baik. Pengetahuan yang rendah ini juga terlihat dari hasil pre-test yang dilakukan dimana mayoritas tingkat pengetahuan ibu masih rendah tentang SADARI dan kanker payudara.

Setelah dilakukan edukasi terdapat peningkatan pengetahuan yang signifikan sebelum dan sesudah tentang pengertian dan stadium pada kanker payudara, gejala dan tanda kanker payudara, faktor resiko kanker payudara, pengertian dan cara melakukan SADARI, manfaat SADARI. Hal ini menunjukan efektifitas penggunaan media edukasi berupa leaflet, video SADARI, dan media patung 
tubuh dalam penyuluhan dan edukasi dalam peningkatan pengetahuan wanita khususnya ibu-ibu tentang kanker payudara dan SADARI.

Rata-rata skor pengetahuan pada saat dilakukan pretest adalah 65,61 dengan standar deviasi 13,36. Rata-rata skor pengetahuan posttest setelah dilakukan penyuluhan adalah 91,95 dengan Sd 15,42. Berdasarkan analisis uji statistik didapatkan nilai $p$-value $=0,02$. Hal ini menunjukan terdapat perbedaan yang signifikan pengetahuan tentang SADARI sebelum dan sesudah dilakukan edukasi dimana rata-rata pengetahuan meningkat sebesar 26,34 point. Hasil ini menunjukan keberhasilan metode dan media edukasi yang dilakukan.

Hal ini sejalan dengan kegiatan penyuluhan yang dilakukan oleh Wantini (2016) dengan metode ceramah, demonstrasi, dan praktik dengan media yang dipakai adalah audio visual berupa video dan leaflet dimana penyuluhan efektif yang dilakukan untuk meningkatkan pengetahuan peserta dilihat dari hasil uji paired sample t-test, terlihat nilai mean perbedaan pengetahuan sebelum penyuluhan dan sesudah penyuluhan sebesar 2,92 dengan standar deviasi 15,79.

Hasil kegiatan ini juga sejalan dengan kegiatan yang dilakukan oleh Yulinda (2018) Pemilihan metode ceramah dengan media audiovisual berupa video penyuluhan kesehatan didapatkan lebih efektif dalam memberikan pemahanan terkait SADARI karena diketahui bahwa terdapat peningkatan pengetahuan dan juga sikap pada sasaran kegiatan dimana sasaran dapat menerima pesan yang ingin disampaikan melalui ceramah yang disampaikan narasumber dan video yang ditayangkan.

Pada kegiatan ini peningkatan pengetahuan yang signifikan setelah dilakukan edukasi juga dimungkinkan karena setelah edukasi dan pelatihan SADARI dilakukan dilanjutkan dengan praktek langsung oleh peserta kegiatan dalam melakukan SADARI dimana efektifitas kegiatan edukasi akan lebih terlihat jika peserta melakukan praktek langsung.

\section{SIMPULAN}

Setelah dilakukan edukasi terdapat peningkatan pengetahuan yang signifikan tentang pengertian dan stadium pada kanker payudara, gejala dan tanda kanker payudara, faktor resiko kanker payudara, pengertian dan cara melakukan SADARI, manfaat SADARI. Hal ini menunjukan efektifitas penggunaan media edukasi berupa leaflet, video SADARI, dan media patung tubuh dalam penyuluhan dan edukasi dalam peningkatan pengetahuan wanita khususnya ibu-ibu tentang kanker payudara dan SADARI.

\section{UCAPAN TERIMAKASIH}

Keberlangsungan kegiatan pengabdian masyarakat ini dapat terlaksana dengan baik dengan dukungan dari pihak-pihak terkait. Tim Pengabdian masyarakat mengucapkan terima kasih yang sebesar-besarnya kepada LPPM Universitas Pembangunan Nasional Veteran Jakarta untuk dukungan dana yang diberikan. Terima kasih sebesar-besarnya juga disampaikan kepada para Ibu Majlis Taklim di Wilayah Kelurahan Cipayung Kota Depok 


\section{DAFTAR PUSTAKA}

Kemenkes. 2015. Infodatin: Situasi Penyakit Kanker. Jakarta. Kementrian Kesehatan RI.

Kemenkes. 2015. Pedoman Teknis Pengendalian Kanker Payudara dan Kanker Leher Rahim

Ayu, Shinta Arini Dan Rilyani. 2016. Pengaruh Penyuluhan Kesehatan Terhadap Keterampilan Remaja Putri Dalam Melakukan Sadari Sebagai Upaya Deteksi Dini Kanker Payudara Di SMA Kartikatama Metro Tahun 2016. Jurnal Kesehatan Holistik (The Journal of Holistic Healthcare), Volume 10, No.3, Juli 2016:1-4

Kemenkes. 2015. Peraturan Menteri Kesehatan Republik Indonesia Nomor 34 Tahun 2015 Tentang Penanggulangan Kanker Payudara Dan Kanker Leher Rahim

Kemenkes. 2019. Hari Kanker Sedunia 2019. https://www.depkes.go.id/article/view/19020100003/harikanker-sedunia-2019.html

Angrainy, Rizka. 2017. Hubungan Pengetahuan, Sikap Tentang SADARI Dalam Mendeteksi Dini Kanker Payudara Pada Remaja. Journal Endurance 2(2) June 2017

Yulinda, Arif 2018. Efektivitas Penyuluhan Metode Ceramah Dan Audiovisual Dalam Meningkatkan Pengetahuan Dan Sikap Tentang Sadari Di SMKN 5 Surabaya. Jurnal Promkes Vol. 6 No. 2 Desember $2018: 116-128$

World Health Organization. 2015. Breast Cancer. [Online] Available at http://www.who.int/cancer/detection/breast cancer/en/index.html. [Accessed October 28th 2017].

International Agency for Research on Cancer (IARC). 2012. Globoca, Lyon.

Wantini, Nonik Ayu. Penyuluhan Deteksi Dini Kanker Payudara Dengan Periksa Payudara Sendiri (Sadari) Di Dusun Candirejo, Tegaltirto, Berbah, Sleman. RAKERNAS AIPKEMA 2016 "Temu IImiah Hasil Penelitian dan Pengabdian Masyarakat" 